\title{
The Concept of Nuestra América [Our America] in José Martí
}

Francisca López-Civeira

Historian

School of Philosophy and History

University of La Habana Cuba

Received: 4/08/2018

Accepted: 10/11/2018

DOI:http//doi.org/10.15359/tdna.35-65.4

\begin{abstract}
The article presents the process of construction of the concept "our America" by José Martí, as well as its importance as a fundamental pillar in Marti's continental strategy. The analysis of the reality and the problems of the independent Latin America seen in Mexico, Guatemala and Venezuela, as well as the examination of the North American (USA) society opened the possibilities for the elaboration of this concept, which contained a continental strategy to overcome the internal problems and the external dangers.
\end{abstract}

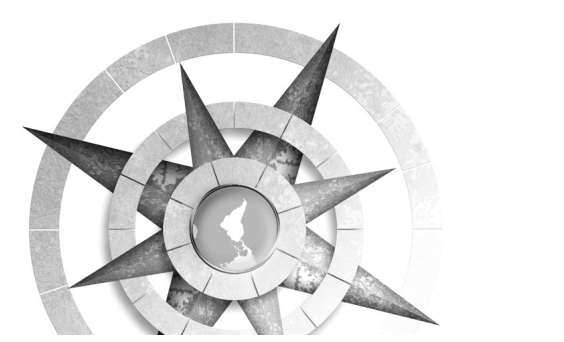

Keywords: Our America; José Martí, Latin American Strategy, Latin American Thought

\section{Resumo}

$\mathrm{O}$ artigo analisa o processo de construção do conceito "Nossa América" de José Martí, bem como sua importância como pilar fundamental na estratégia continental de Martí. A análise da realidade e dos problemas da América Latina independente vistos no México, Guatemala e Venezuela, e o exame da sociedade americana, abriram as possibilidades para a elaboração do conceito, que continha uma estratégia continental para superar problemas internos e perigos externos.

Palabras chave: Nossa América, José Martí, estratégia latino-americana, pensamento latinoamericano 


\section{Resumen}

El artículo analiza el proceso de construcción del concepto "Nuestra América" por José Martí así como su importancia como pilar fundamental en la estrategia continental martiana. El análisis de la realidad y de los problemas de la América Latina independiente vistos en México, Guatemala y Venezuela y el examen de la sociedad estadounidense, abrieron las posibilidades para la elaboración del concepto, el cual contenía una estrategia continental para superar los problemas internos y los peligros externos.

Palabras clave: Nuestra América, José Martí, estrategia latinoamericana, pensamiento latinoamericano

José Martí is one of the greatest thinkers of $19^{\text {th }}$. Latin America; however, despite the time that has elapsed, his ideas maintain an amazing relevance in the context of the 21st century. Among the most significant issues of Marti's thought, is the concept of "our America" with which he grouped the American region south of the río Bravo. This construction was not sudden nor the result of a purely emotional inspiration, rather it was built throughout Martís own experience while experiencing different scenarios and due to his ability to delve into history and foresee the possible future course.
The first contact of the Cuban deportee with the reality of independent Latin America was in 1875, upon arriving in México; therefore, it would be a capital moment. His previous experience had developed in his native Cuba, still a colony of Spain and fixed with the infamous institution of slavery still in full force. He then lived as a deportee in the metropolis where he saw the establishment and fall of the Primera República [First Republic]; thus in México he came into contact with a new world where independence and republican life had been achieved, goals for which the Cuban people were fighting and the young Martí had embraced which cost him imprisonment, forced labor and exile from Cuba. His entry into México, therefore, meant the discovery of a very new reality for him.

\section{The revelation of "our America"}

The Mexican land offered the possibility of knowing the world of an America, former Spanish colony, living a process of liberal reforms, within a republican system impregnated with social conflicts such as the drama of the American "Indian", the struggles among political groups and debates on economic problems that included the commercial relationship with the United States, among the most notorious. 
One of the first issues observed and raised by the Cuban was the need to find proper ways to solve our problems, as he perceived that formulas derived from different societies were assumed but due to their differences with Latin American reality, did not offer an adequate solution to our needs. Europe and the United States were very different societies, therefore, the servile stencil of their models was not useful in our countries, hence his affirmation in 1875 , referring to theater, but encompassing a much broader comprehensive sense: "A new nation needs new literature. This exuberant life must be manifested in its own way. [...]." Then, he added: "American life does not develop, it sprouts". He characterized our "new" nations, resultant of the fusion of the autochthonous with the European, as "thinking in a more enlightened way, they feel in a more loving way", so theatrically it should be expressed as "original sprouting of new types" and not as "servile copies of exhausted nature" (Martí, 2002, Vol. 6, pp. 199-200). This is how he expressed his first approximations of an American world that he felt self-determined and original which he contrasted with other realities.

The idea of a "pueblo nuevo"1 would be present again in Guatemala, when he said:

1 Editor's note: pueblo nuevo meaning not only the resulting "new peoples" from the clash of Spaniards and native Americans during the conquest, but this new human beings restoring their history in our America.
Interrupted by conquest, the natural and majestic work of the American civilization, a strange, non-spanish nation was created with the advent of Europeans, because the new sap rejects the old body; not indigenous, because interference (sic) of a devastating civilization has been suffered, two words that, although being antagonistic, constitute a process; a mestizo people was created in a way, that with the reconquest of its freedom, develops and restores its own soul. (Martí, Vol. 7, p. 96)

Martí thus arrived at his first essential definitions that, moreover, opposed him to the then extended concept of "civilization against barbarism" where the original American was the barbarian. Because of this, he would later say in an advance of his own definition of our American: "It is not that the American intelligence rejects depth; it is that it needs to go down a bright path towards it. $/[\ldots]$ the exuberance of these virgin nations, powerfully manifests itself in all forms." (Revista Universal, in Martís Vol. 6, p. 235-236).

The sense of looking for own forms, as opposed to the servile copy of European or the United States, also took root in the young Cuban in those initial moments, which is seen in his frequent statements in México, for example, when he states: "To own history, own solutions. To our life, our laws"; this led 
him to call for the creation of an economy in correspondence with the life that was being formed and to enact "original and concrete" (Vol 6, p. 312) laws in harmony with the conflicts brought upon by life itself. From this idea emanated another very specific belief: "The servile imitation misleads, in economy, as in literature and politics.” (p. 312)

On October 26, 1875, Martí, referring to the need to potentiate our forces, established the comparison, not only with Europe, but also within what he would later call "two continental factors", indicating the differences that characterized us:

And, what forces would not be discovered in us, throwing Victor Hugo's heaps of light on our eight million inhabitants? And just as in us, also in all of South America. We are not yet quite American: every continent must have its own expression: we have a legacy of life, and stammering literature. There are perfect men in America seen through the optics of European literature; but we yet do not possess an exclusively American litterateur. There must be a poet who looms over the summits of the Alps of our Sierra, of our haughty Rockies; a powerful historian more worthy of Bolivar than of Washington, because America is the outburst, the sprouting, the revelations, the vehemence, and Washington is the hero of calmness; formidable, but placid; sublime, but tranquil. (Martí, Vol. 6. p. 352)

The Washington-Bolivar contrast is very significant, in this case, to define different sensibilities of nations with different characteristics. Also of his encounter with México resulted a first expression that would become paradigmatic: "If Europe were the brain, our America would be the heart. Others will think more; nobody will feel deeper." (Vol. 6, p. 423) Martí did not affirm but expressed in a potential sense the difference between Europe and "our America", when for the first time he used this expression that he would deepen and develop in later years. Also while in México, when deciding his departure, he wrote the about the motherly meaning of this land: "And when I see the American land, sister and mother of mine, (...)." (p.362). Since he felt this land as being his mother, he placed himself in the condition of a son, with the duties this entailed.

These first expressions, samples of the "discovery" of our America, would have important continuity in Guatemala, where he defined geographical spaces and symbols belonging to that world that he began to see as one and own. In Homeland and Freedom. Indian Drama, which he wrote upon request 
to commemorate independence, he embodied relevant definitions placed in the voice of the character recalled by Martino:

I am the sheep
that turns indomitably before the wolf
and lifeless and astonished he leaves
him
with the weapon of Maipu and Cara-
bobo!
Of Hidalgo is my voice. I am Boli-
var's
burning gaze. I am the ray
of eternal justice, in which
embosomed
America is reborn,
from the sources where the Bravo
is born
to the deserted Paraguayan forest!
(Martí, Vol. 18, p. 162)

It is very significant the way in which he unites the historical process as one through symbols such as battles and very representative characters, while also defining the physical space occupied by "our America".

In that initial discovery an additional factor also appears: the relationship with the other America. In México, Martí analyzed the bilateral trade issue, which retained his interest in subsequent years. In 1883 he would return on this subject when a commercial treaty came into the scene, about which he stated that there was "no event of major gravity for the peoples of our Latin America than the commercial treaty that is projected between the United States and México." (La América, in Martí, 1883, Vol. 7, p. 17). He considered it as a dangerous vicinity and warned about this. This preoccupation, that extended for all America south of the Río Bravo, was reflected in some notes, apparently written while in a trip to the Mexican city of Veracruz in 1876, where he noted:

Yes: description of what I see. México grows. It ought to grow for its defense, while its neighbors grow for its greed. It must be worthy for the world, when at its doors the battle of the world is seen to be fought. Who will America be: Rome or America, Cesar or Spartacus? What does it matter for Caesar not to be an individual, but the nation, as such one, is it Caesarean? Down with American Caesarism! The Spanish speaking lands are those that must save freedom in Am.! [...]. (Vol. 19, p. 21-22) $)^{2}$

This note is very clear about Martís concern about the dangers he observed within the continent, and also about his focus beyond a country, as he addresses the entire Spanish speaking area, but it is the Aztecs ${ }^{3}$ who are closer

2 The following annotation is included in the cited Obras Completas: "It seems that these notes were taken by Martí on the trip from Veracruz to Mexico City (1875)"; however, Herrera Franyutti locates them in 1876, when Martí went from Mexico to Veracruz.

3 Translator's Note: the Mexicans 
to the "caesarean nation", hence he exclaimed: "Oh dear México, see the dangers that surround you! Hear the cry of your son who was not born of you! In the north a perverse neighbor curdles [...]" (Vol. 19, p. 22)

\section{The consolidation of the common homeland in Martí}

In April 1877, the 24-year-old Cuban was in Guatemala, where he continued his observation of a society independent of Spanish colonialism, with processes and situations that maintained certain similarities with the observed in México. There he refined the vision of our America, not only in its geographic space and in our American culture, but also included new aspects.

In his analysis of the "New Codes", he pointed out the importance of changing laws, since once "a social State is broken" the laws need be shattered to respond to that new State. Hence, although the codes were not perfect, as was neither the transitional society, he claimed: "At last one is American in America, the Republic lives republican [...]!" (Vol. 7, p. 102). That is to say, it was important to create the bases of the independent republican life from the change that had to be operated.

In Guatemala, it is perceived how the Cuban continues to be fascinated with the our American nature which he calls robust, and reiterates the comparative sense to exalt our values; but most importantly is the way in which he analyzes problems common to us and the need for transformation of the societies that had achieved independence without completing the revolutionary change; this, he expresses with clarity in a letter dated November 27, 1877: "The way to celebrate independence is not, in my judgment, to deceive oneself about its meaning, but to complete it." In the letter to Valero Pujol, he said: "I am talking about what I always talk about: of this unknown giant, of these lands that babble, of our fabulous America. I was born in Cuba, and will be in the Cuban land even when stepping in the untamed Arauco plains. The soul of Bolivar encourages us; the American thought transports me." This recognition was accompanied by a sense of life: "Live humble, work hard, aggrandize America, study its strengths and reveal them to her, retribute its nations the good they do to me: this is my job." (p. 110-112).

José Martí showed great concern for the problems that divided our America, which meant weakness and danger. In the brochure Guatemala, published in México in 1878, he already inquired about this situation: "But what shall we do, indifferent, hostile, disunited? What will we all do to give more color to the sleeping wings of the insect? For the first time it appears to me that
62 The Concept of Nuestra América [Our America] in José Martí Francisca López-Civeira

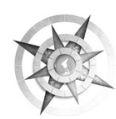


a chain comes into good use to tie and enclose all the peoples of my America!" However, his concept of unity as aspiration did not remain as a mere query and affirmation, instead he resorted to history to evidence the danger of disunity: "Pizarro conquered Peru when Atahualpa warred Huáscar; Cortés defeated Cuauhtémoc because Xicotencatl assisted in its devise; Alvarado entered Guatemala because the Quichés surrounded the Zutujiles. Since disunion was our death, what vulgar understanding, nor petty heart, is necessary to be told about the fact that our life depends on our unity?" (p. 118).

The almost dramatic way of showing what division had meant in the past was the way to call attention to the need for union, but it was not only the call, he also placed his work ahead for the cause, his sense of doing: "I live to unite what misfortune disunited. We must know here what is being done and permitted elsewhere, way beyond the Chiapas border. The hands are extended; this is the hour." (p. 119). This affirmation regarding what was intended was a constant idea in his expressions, which indicated the sense of what he should do as a duty. On September 21, 1877 he wrote to his Mexican friend Manuel Mercado: "To give life to America, to resuscitate the old one, to strengthen and reveal the new one.." (Vol. 20, p. 32), as a sense of his life, in which forging unity constituted an essential objective. The year 1880 was very convulsive in the life of Martí. After his return to Cuba, his incorporation to the independence conspiracy, his new exile and his clandestine exit to the United States, and his incorporation in New York to the Revolutionary Club of that city, while in Cuba a new conflagration for independence developed, known as Guerra Chiquita for its short duration of about a year, he completely devoted himself to work in that Club of which he became interim president. After the war ended, in the first semester of 1881, he relocated to Caracas, which he called "the Jerusalem of America" because it was the birthplace of Bolivar. It would be the third country of our independent America in its life experience.

In that land where, as he wrote later, without asking where to eat or sleep, it was before the statue of the Liberator who he felt should be loved as a father, that he continued his analysis of our problems and possible future. In a speech at the Commerce Club of Caracas, on March 21, 1881, he stated: "It is known that the poem of 1810 lacks a verse" ( Vol. 7, p. 284) with which it he was reaffirming the sense of the in unison process of independence of our lands, since it referred to the fact that he wanted to write that verse with the new Cuban feat; but it was in the letter to Fausto Teodoro de Aldrey, of July 27, 
1881, where one of Marti's most wellknown expressions was used: "I am a son of America: I owe myself to her. And of America, to whose revelation, shaking and urgent founding I consecrate myself, this is the cradle." (p. 267).

It can be noticed that, with his stay of one semester in Venezuela, Martí had completed a cycle in the formation of his thought and in the creation of the concept of "our America" that was accompanied by a sense of life, of a strategy that contemplated unity as an essential factor, in which there is the conviction of filial duty. Our America is the mother so the children have duties to fulfill and Martí affirms that certainty from his personal disposition.

In the second semester of 1881 Martí returned to the United States, to reside in New York, almost uninterruptedly, until January 1895. That time was very important for the preparation of the Revolution that was to enter a new period of war, as himself affirmed; but it was also of extraordinary value for his analysis of American society and, therefore, for the completion of his our American strategy.

From the northern land, Martí wrote for newspapers that reached our countries or that were published locally. México, Honduras, Colombia, Argentina, among others, were countries in whose press the works of the Cuban constantly appeared. In 1883, in La América, which was published in New York, he already proclaimed:

All our desire is to put soul to soul and hand to hand the nations of our Latin America. We see colossal dangers; we see an easy and brilliant way to avoid them; we guess, in the new adaptation of the world's national forces of the world, always in motion, and now accelerated, the necessary and majestic grouping of all the members of the American national family. To think is to foresee. It is necessary to start bringing together what must end up being together. If not, hatred will grow; will be left without proper defense against the colossal dangers, and will live in perpetual and infamous battle between brothers for appetite of land. (Vol. 7, p. 325)

In that article, Martí returned to the problem of unity, in comparative terms, to evidence our various more favorable conditions: "In South and Central America, as in Europe and Asia, there are no inevitable battle reasons of rival races, that justify and explain wars, and make them systematic, inevitable, and at certain moments required. Why would the nations of the Americas fight, if not for puerile vanities or ignominious hunger? Horrible wars, the wars of the greedy!" (p. 325)
64 The Concept of Nuestra América [Our America] in José Martí Francisca López-Civeira

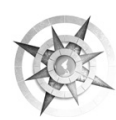


In the order of comparisons, he later insisted, repeatedly. In 1891, he said in El Partido Liberal of México, that "neither with Gauls nor with Celts do we have to do in our America, but with creoles and indians." (p. 59). There were other problems that began to take hold, as he indicated in a letter to Roque Sáenz Peña in April 1890, calling him to work together to "confirm our independence before the appearance, as they could originate, of the conditions that can take it away from us." In this purpose he linked the independence of Cuba as "I want her to go about, saving herself and saving others, wherever our America goes." (p. 398).

\section{The maturation of the concept}

At the end of the eighties and beginning of the nineties, Martí had matured his ideas, his revolutionary project and his strategy for realizing it; as part of this, one can appreciate his view of "our America”, which was an essential component of such projections. In this regard, it is essential to remember events that led him to hasten the formulation of the body of ideas expressed in the essay "Our America", published in January 1891 or, previously, his speech known as "Mother America" delivered on 19 December 1889. The International American Conference, held in Washington between 1889 and 1890, and recognized as the first Pan-American conference, constituted a moment of alarm for Martí, followed by the Monetary Conference of 1891, which confirmed his apprehensions.

On the occasion of the first mentioned meeting, Martí followed closely the activities that unfolded, such as the touring of the Latin American delegates throughout different areas of the United States, as well as the discussions of the conclave that began on October 2, 1889 and culminated on April 19 of the following year. He was not a delegate, but related with some of those present at that meeting, especially with Gonzalo de Quesada, the Cuban who attended as secretary of the Argentine delegate. In his correspondence he refers insistently to the project of annexation of Cuba and to the dangers posed by that North American (USA) convocation. Continental newspapers published in their pages chronicles of alert and proposals of attitudes that should be assumed. In particular, some chronicles published in La Nación of Buenos Aires, are of great interest. That published November 2, presented with all harshness the problem as perceived by him:

There never was in America, of the independence here, a matter that requires more reasonableness, nor force to more vigilance, or ask for more clear and thorough examination, than the treat that the United States, powerful, full of unsellable products, and determined to extend their domains in America, make 
to the less powerful American nations, bound by free and useful trade with the european nations, to align a league against Europe, and seal treaties with the rest of the world. From the tyranny of Spain, Spanish America was able to escape; and now, after seeing with judicial eyes the antecedents, causes and factors of the treat, it is urgent to say, because it is the truth, that time has come for Spanish America to declare its second independence. (International congress of Washington, 1889, in Martí Vol. 6, p. 46).

After alerting with this reflection about the intention of the "treat" of the United States, which included the problems in the international sphere; he went on to present what could be done during the historical time that was being lived:

Only a unanimous and virile response, for which there is still time without risk, can free at once the spanish nations of America from restlessness and disturbance, fatal in their time of development, in which they would have them without ceasing, with the possible complicity of the venal or weak republics, the secular and confessed policy of predominance of a thriving and ambitious neighbor, who has never wanted to encourage them, nor has it directed to them but to prevent their extension, as in
Panamá, or seize their territory, as in México, Nicaragua, Santo Domingo, Haiti and Cuba, or to cut off by intimidation their dealings with the rest of the universe, as in Colombia, or to force them, as now, to buy what they cannot sell, and to confederate themselves for their domination. (pp. 46-47)

It was a recount from recent history to evidence the real danger at hand. At the end of the first part of this chronicle, a comparison was presented that allowed the understanding of his approach:

The Sun of New York, said it yesterday: "Whoever does not want to be crushed by the Juggernaut, get inside your car." It will be better to close the road to the car. That's what genius is for: to overcome force with skill. Texans climbed inside the car, and with the fire on their backs, like rabid foxes, or with their house dead on the rump, they had to go out, barefoot and hungry, from their Texas land. (p. 54)

The urgency he felt by the interests that moved behind the United States invitation led Martí to publicly expose some of his apprehensions, which were based on the existence of two portions in America that were different in origin, 
history and interests, a matter of great value for the formulation of his concept of our America:

On the one hand there are nations in America who proclaim their right of self-coronation to rule, by geographical morality, on the continent, and announce, through the mouths of their statesmen, in the press and in the pulpit, at the banquet and in the congress, while they put their hands on an island and try to buy another, that all of the north of America must be theirs, and that their imperial right of the isthmus below must be recognized; and on the other hand, are the nations of diverse origin and purpose, every day more occupied and less suspicious, who have no real enemy but their own ambition, and that of the neighbor who invites them to spare him the job of taking away tomorrow by force what can now be given at will to him. And must the nations of America put their businesses in the hands of their only enemy, or gain time, and settle, and unite, and definitely deserve the credit and respect of nations, before the neighbor dares to demand submission, by the lessons of inside or outside, their will can be moderated, or their political moral educated, before it is determined to incur in the risk and opprobrium to shadow, for the reason of being in a same continent, over decent nations, capable, just, and like him, prosperous and free? (p. 56) .

From this, his question to the nations of our America: "Why go as allies, in the best of youth, in the battle that the United States is preparing to wage with the rest of the world? Why should they fight battles over the republics of America with Europe, and rehearse their colonization system in free nations?" (p. 57)

The extension of the quotations incorporated herein are inevitable to understand Martís expositions and his urgency to unveiled them, as nothing is more eloquent than his own words. Undoubtedly, the International Congress of Washington was a transcendent event that led him to an almost immediate exposure of the concept and the strategy that should be followed. A first step was his speech on December 19 before the delegates to the Conference on the Hispano-American Literary Society, in New York, where he made a comparative story among those that he already identified as two Americas and established the origin of the differences from a historical perspective, what he synthesized in the expression: "From the plow was born North America, and Hispaniola of the prey dog." (Vol. 6, p. 136). At the end of this speech he uses the term "mother America”, hence 
he is known by that expression; but in January of 1891 he reached the culminating moment of this process, when he published his essay "Our America". The concept had matured and his exposition could not be postponed.

From the first paragraph the call to awaken before the danger "of the giants that have seven-league boots" is set forth, and he added by "the fight of the comets in the sky, that cross the air asleep gobbling worlds"; reasons that called for times to put away the pillow weapons and reaffirm that we are dealing with the weapons of ideas, because "trenches of ideas are worth more than stone trenches." (Vol. 6, pp. 15-23)

In view of the danger described from the beginning of the text, there is a call to unity in peremptory terms: "the trees ought to line up, so that the giant of the seven leagues will not pass! It is the hour of recount, and of the united march, and we ought to walk in a tight square, like the silver in the roots of the Andes." It is evident the intentionality to begin the exposition with an alert and a call of urgency to the readers. Next, he would expose a set of ideas, with rationalizations and explanations given in compact blocks, where he begins by showing the need for the identification of ourselves with our land

4 The essay is found in Volume 6 of the cited edition, pages $15-23$, therefore all citations following are from this reference. and, therefore, create from our reality the solutions to our problems, because "A Hamilton decree will not buck up the chest of the plainsman's colt. With a phrase by Sieyes, the curdled blood of the indian race is not unclogged." Therefore, "The government ought to be born from the country. [...]."

Next, Martí faces Sarmiento's formulation, very widespread at that time: "[...] There is no battle between civilization and barbarism, but between false erudition and nature." Affirmation that continues with the explanation of its content and culminates when expressing that "The national politicians ought to replace the exotic politicians. Let the world graft in our republics; but the trunk must be that of our republics." As can be seen, it is not a question of rejecting outside experiences on a whim, but rather of taking what is useful from one's own base.

One of the most relevant issues of the Our America essay is the view given of the non-realization of revolutionary change and the content of such change. Martí proclaims: "The problem of independence was not the change of forms, but the change of spirit." What is followed with the explanation: "With the oppressed we had to make common cause, to strengthen the system opposed to the interests and command habits of the oppressors." It is very evident that Martí understood that it 
was about making the cultural revolution, to break away from the colonial mechanisms and mentalities, for which the participation of the oppressed was fundamental, the oppressed which he would later name when dealing with the peasant, the black, the Indian. But he also warned of the internal and external dangers, when speaking of the inside and outside "tiger", of that tiger that "returns at night to the place of the prey", with velvet claws, his coming is not heard, but when the prey awakens "he has the tiger on top", by which he was warning of the internal dangers, of how "the colony continued to live in the republic"; but also warns of "tiger from outside".

Martí exposed in this essay what he considered at that time to be, "the greatest danger" derived from "the difference in origins, methods and interests between the two continental factors, and is next in time for it to come by, demanding intimate relations, to an enterprising and thriving peoples that ignores and disdains it." For the Cuban, "The disdain of the formidable neighbor, who does not know her, is the greatest danger of our America." Before this, it is "urgent, because the day of the visit is close, that the neighbor gets to know her, know her soon, so that he would not disdain her. [...]" Therefore, our America had urgent duties to fulfill. The publication of the essay Our America is an essential moment in the maturation of a concept and a strategy that was built over time, the experiences and reflections of Martí, what he did within a sense of life, of fulfillment of duty of the son of "Mother America", hence, when the Cuban war of independence broke out in 1895, its great leader addressed Latin American men from the perspective of the importance of that feat for our America. He wrote to the Dominican Federico Henriquez y Carvajal on March 25: "The free Antilles will save the independence of our America, and the already doubtful and hurt honor of English America, and perhaps accelerate and settle the balance of the world. See what we do, you with your youthful gray hair, and I, dragged, with my broken heart." (Vol. 4, p. 111). While on May 18 he told his Mexican friend Manuel Mercado that he was already in danger of giving his life for his country and "because it is my duty-since I understand it and I have the courage to do so-to timely prevent with Cuba's independence the advancement of the United States across the Antilles and cause their fall, due to that additional force, over our American lands." (p.167). At the same time, he asked if México would not help those who defended it, to affirm "This is death or life, and there is no erring." (p. 169)

The sense of "our America”, which contains a strategy and a vocation of fulfillment of the duty towards the land that feels like a mother, is one of the fundamental axes of Martían thought, which 
remains absolutely current for the people who live south of the río Bravo; thus its study does not only pertain to the past, but from that past it can be projected to the present and the future. It is a matter of absolute topicality. 